\title{
Lise Öğrencilerinin Akademik Erteleme Davranışlarının Yordanmasında Bilişsel Esneklik ve Ruminasyonun Etkisi
}

\author{
Doç. Dr. Müge Yukay Yüksel ${ }^{1 *}$ \\ Arş. Gör. Mine Sayın² \\ Öğr. Gör. Serra Dinç ${ }^{3}$
}

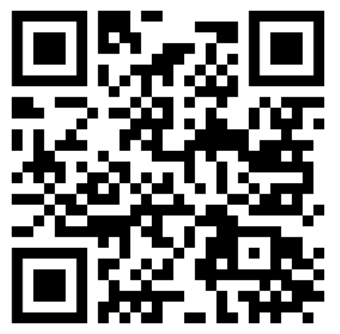

Geliş tarihi: 16.09.2020

Kabul tarihi: 27.10.2020

Atıf bilgisi:

IBAD Sosyal Bilimler Dergisi

Sayı: Özel Sayı Sayfa: 202-218

Yll: 2020

This article was checked by iThenticate. Similarity Index 8\%

Bu makalede araştırma ve yayın etiğine uyulmuştur.

${ }^{1}$ Marmara Üniversitesi, Türkiye, muge.yuksel@marmara.edu.tr ORCID ID 0000-0002-7425-2716

${ }^{2}$ Bartın Üniversitesi, Türkiye, mine.sayin@marmara.edu.tr. ORCID ID 0000-0001-6875-7307

${ }^{3}$ Sağlık Bilimleri Üniversitesi, Türkiye, serra.dinc@sbu.edu.tr.

ORCID ID 0000-0001-6434-3166

* Sorumlu yazar öz

Yapılan çalışmada lise öğrencilerinin akademik erteleme davranışlarının azalmasında bilişsel esneklik seviyelerinin yükselmesi ve ruminatif düşüncelerinin azalmasının, etkisi olup olmadığını tespit etmek amaçlanmıştır. Çalışmada, 297 lise öğrencisi yer almaktadır. Akademik Erteleme Ölçeği, Bilişsel Esneklik Ölçeği ve Ruminasyon Ölçeği Kısa Formu bu çalışmada kullanılan ölçeklerdir. Akademik erteleme düzeyini yordamada bilișsel esneklik ve ruminasyon değişkenlerinin rolünü saptamak amaçlanarak çoklu regresyon analizi yapılmış, bu değişkenlerin akademik ertelemeyi anlamlı bir şekilde yordadığı görülmüştür. Analiz sonuçlarına göre, bilişsel esneklik ve ruminasyon değişkenleri ikisi birlikte, akademik ertelemedeki toplam varyansın yaklaşık \%11'ini açıklamaktadır. Cinsiyete göre ayrı ayrı incelendiğinde de öğrencilerin akademik erteleme düzeyini yordamada bilişsel esneklik ve ruminasyon değişkenlerinin rolünü saptamak amacıyla çoklu regresyon analizi yapılmış, kız ögrencilerde de erkek ögrencilerde de bu değişkenlerin akademik ertelemeyi anlamlı bir şekilde yordadığı görülmüştür. Analiz sonuçlarına göre, kız öğrencilerin bilişsel esneklik ve ruminasyon puanları ikisi birlikte, akademik ertelemedeki toplam varyansın yaklaşık \%12'sini açıklamaktadır. Erkek öğrencilerin ise bilişsel esneklik ve ruminasyon puanları ikisi birlikte, akademik ertelemedeki toplam varyansın yaklaşık \%10'unu açıklamaktadır. Sonuç olarak, akademik erteleme davranışı gösteren öğrencilerin bilişsel esnekliklerinin ve ruminasyon düzeylerinin bu durumu etkilediği görülmektedir. Akademik erteleme düzeyi arttıkça bilişsel esneklik düzeyinin azaldığı ortaya çıkmıştır. Araştırmanın diğer sonucu ise, ruminasyon düzeyinin arttıkça akademik erteleme davranışlarının arttığını göstermektedir. Kız ve erkek öğrenciler için ayrı ayrı incelendiğinde, kız öğrencilerin akademik erteleme ve bilişsel esneklik puanları arasındaki ilişki, erkek öğrencilerin akademik erteleme ve bilişsel esneklik puanları arasındaki ilişkiden daha yüksektir. Bilişsel esneklik puanlarına bakıldığında da kız öğrencilerin puanlarının erkek öğrencilerden daha yüksek olduğu görülmektedir. Öğrencilerin ruminasyon puanları incelendiğinde, araştırma sonucuna göre kız ve erkek öğrencilerin ruminasyon puanları arasında anlamlı bir farklılık bulunmamıştır. Bir başka sonuç ise bilişsel esneklik ile ruminasyon arasında negatif yönde anlamlı bir ilișki olduğudur.

Anahtar Kelimeler: Akademik erteleme, bilişsel esneklik, ruminasyon 


\title{
The Effect of Cognitive Flexibility and Rumination on Predicting Academic Procrastination Behavior of High School Students
}

\author{
Assoc. Prof. Dr. Müge Yukay Yüksel ${ }^{1 *}$ \\ Res. Assist. Mine Sayın ${ }^{2}$ \\ Lect. Serra Dinç ${ }^{3}$
}

First received: 16.09 .2020

Accepted: 27.10 .2020

\section{Citation:}

IBAD Journal of Social Sciences

Issue: Special Issue Pages: 202-218

Year: 2020

This article was checked by iThenticate. Similarity Index 8\%

\author{
${ }^{1}$ Marmara University, Turkey, \\ muge.yuksel@marmara.edu.tr, \\ ORCID ID 0000-0002-7425-2716 \\ ${ }^{2}$ Bartın University, Turkey, \\ mine.sayin@marmara.edu.tr, \\ ORCID ID 0000-0001-6875-7307 \\ ${ }^{3}$ University of Health Sciences, Turkey, \\ serra.dinc@sbu.edu.tr \\ ORCID ID 0000-0001-6434-3166
}

* Corresponding Author

\begin{abstract}
In this research, it is aimed to determine whether high levels of cognitive flexibility and low levels of rumination have an effect on decreasing academic procrastination behaviors of high school students. The study includes 297 high school students. Academic Procrastination Scale, Cognitive Flexibility Scale and Rumination ScaleShort form have been used in the study. Multiple Regression Analysis was conducted in order to determine predictive role of cognitive flexibility and rumination on academic procrastination, and it was found that these variables significantly predicted academic procrastination. According to the analysis results, cognitive flexibility and rumination variables together explain approximately $11 \%$ of the total variances in academic procrastination. When analyzed separately by gender, the results of multiple regression analysis have showed that cognitive flexibility and rumination have significantly predicted academic procrastination in both girls and boys. According to the results, girls' cognitive flexibility and rumination scores together explain approximately $12 \%$ of the total variances in academic procrastination. The cognitive flexibility and rumination scores of boys together explain approximately $10 \%$ of the total variances in academic procrastination. As a result, it is seen that the cognitive flexibility and rumination levels of the students showing academic procrastination behavior affect this situation. According to the results, as the level of academic procrastination increases, the level of cognitive flexibility decreases, and as the level of rumination increases, academic procrastination behaviors increase. When analyzed separately for girls and boys, the relationship between academic procrastination and cognitive flexibility scores of girls is higher than the relationship between academic procrastination and cognitive flexibility scores of boys. When the cognitive flexibility scores are examined, it is seen that the scores of girls are higher than boys. When the rumination scores of the students are examined, results have showed that the difference between the rumination scores of male and female students is not statistically significant. Another result is that there is a negative significant relationship between cognitive flexibility and rumination.
\end{abstract}

Keywords: Academic procrastination, cognitive flexibility, rumination 


\section{GİRIS}

Modern dünyanın rekabete dayalı yaşamı içerisinde zamanında görev ve sorumlulukların tamamlanması gitgide daha önemli hale gelmektedir. Herhangi bir görevin sonuçlarına bakılmaksızın gerçekçi olmayacak şekilde geciktirilmesi, tamamlanmaması, durumun sonucunda üzüntü hissedip hızlı bir şekilde görevi tamamlamaya çalışılması erteleme olarak ifade edilmektedir (Lay, 1986; Neenan, 2008; Solomon ve Rothblum, 1984). Erteleme davranışı olan bireyler hayatın her alanında hılı bir şekilde başladıkları işleri devam ettirememekte ve hedefe ulaşmak için gerekli çabayı gösterememektedirler (Kandemir, 2014). Öğrencilerin sınav hazırlığı, ödevleri zamanında teslim etme gibi akademik konularda gecikme yaşaması veya irrasyonel nedenlerle tamamlamayı başka zamana bırakması durumu ise akademik ertelemedir (Kağan, 2010; Senecal, Julien ve Guay, 2003). Akademik erteleme davranışının sebeplerinden biri kişinin sorumluluk seviyesinin düşük olmasıdır (Johnson ve Bloom, 1995). Sorumluluk seviyesinin düşük olduğu kişilerde akademik ertelemenin yüksek olduğuna dair çeşitli çalışmalar da mevcuttur (Abdi Zarrin, Gracia ve Paixão, 2020; Bulut, 2014; Lee, Kelly ve Edwards, 2006). Bir diğer sebep ise zamanı planlama ve o planı uygulamada sorunlar yaşanmasıdır. Balkıs, Duru, Buluş ve Duru (2006) tarafindan kötü zaman yönetiminin akademik ertelemeye yol açtığı da bulunmuştur. Uzun-Özer, Demir ve Ferrari (2009) ise, Türk üniversite öğrencilerinde başaramama korkusu, tembellik, kontrole karşı çıkma ve risk alma davranışlarını akademik ertelemenin nedenleri olarak tespit etmiştir. Diğer yandan, başa çıkma ve problem çözme becerilerinin de akademik erteleme ile ilişkili bulunan faktörler arasında olduğu görülmektedir (Beleaua ve Cocoradă, 2016; Lay, Edwards, Parker ve Endler, 1989; Sirois ve Kitner, 2015). Yukarıda akademik ertelemeye etkisinden bahsedilen hedef belirleme, planlama, organizasyon, zaman yönetimi, sorumluluk alma, başa çıma ve problem çözme gibi üst düzey bilişsel süreçleri içeren öz düzenleme becerileri ile ilişkili olan bir diğer yürütücü işlev ise bilişsel esnekliktir (Canas, Quesada, Antolí ve Fajardo, 2003; Dennis ve Vander Wal, 2010; Schommer-Aikins ve Easter, 2018).

Bilişsel esneklik, bireylerin durumlara verdiği tepkileri anlamlandırmak için önemli bir değişkendir. Bilişsel esnekliğin belli durumlara uyum sağlama, düşünceler arası geçiş yapabilme, farklı durumlara çeşitli çözümler sağlayabilme, seçeneklerin farkında olma ve yeni durumlara uyum sağlama gibi çok çeşitli tanımı bulunmaktadır (Bilgin, 2009; Silver, Hughes, Bornstein ve Beversdorf, 2004; Stevens, 2009). Bu kavrama göre, kişiler çevresel durumlara göre bilişlerini değiştirmektedirler (Dennis ve Vander Wal, 2010). Alg1, bellek ve hareketle ilgili süreçlerde programlama ve koordinasyon bilişsel esneklik için gereklidir. Bu beceri erken dönemlerde olgunlaşan bir beceridir (Güler, 2009). Bireylerin yaşadıkları zor durumları çözebilmek için çözüm üretme becerisi, olası alternatifleri algılayabilme becerisi gibi bilişsel esnekliği gösteren durumlardır (Dennis ve Vander Wal, 2010). Bilişsel esneklik sadece bilişsel bir süreç değil, aynı zamanda gözlenebilen bir davranış olarak da ele alındığında farklı şekillerde açıklanabilir. Bir görevden diğerine geçiş yapabilme, eş zamanlı birden çok görevi gerçekleştirebilme, çözüm stratejileri geliştirebilme buna örnek olarak verilebilir (Monsell, 2003). Aynı zamanda bilişsel esnekliğe sahip kişiler sorumluluk sahibi bireylerdir (Bilgin, 2017). Bilişsel esnekliğin ilişkili olduğu bir diğer faktör ise ruminasyondur (Anayurt, 2017; Davis ve Nolen-Hoeksema, 2000; Greene, 2019).

Ruminasyon, uyumsuz bir düşünme tarzı olan ruminatif tepki biçimine verilen isimdir (NolenHoeksema, 2000). Kişinin sorunları, bunların nedenleri ve sonuçları üzerine yoğunlaşması, sorunların çözümü için adım atmaksızın, içinde bulunduğu olumsuz duygu durumu hakkında pasif bir şekilde ve devamlı olarak düşünmesi, ruminasyon olarak ifade edilmektedir (Nolen-Hoeksema, 2000). Ruminatif eğilime sahip kişiler, sadece problemlerini ve problemlerin neden olduğu olumsuz duygularını düşünerek, kendilerini dış dünyadan soyutlar ve probleme ilişkin çözüm bulsalar bile bunu uygulamakta başarısız olurlar (Bugay ve Erdur-Baker, 2011). Bu kişiler hem kendileri hem de yaşamları hakkında karamsarlardır. Olayların genellikle olumsuz yönlerine odaklandıkları için olumsuz yaşantılardan daha fazla etkilenme eğilimindedirler (Nolen-Hoeksema, Wisco ve Lyubomirsky, 2008). Treynor, Gonzalez ve Nolen-Hoeksema (2003), ruminasyonun iki alt boyutundan bahseder. Bu alt boyutlar, Erdur-Baker ve Bugay (2012) tarafindan saplantılı düşünme (brooding) ve derin düşünme (reflection) olarak Türkçe'ye kazandırılmıştır. Bu boyutların her ikisi de uyumsuz olmasına rağmen, derin düşünme tarafsız bir şekilde problemlerle başa çıkma arzusu içerirken, saplantılı düşünme problemler hakkında karamsar düşüncelere sahip olmayı içerir. Bu nedenle derin düşünmenin saplantılı düşünmeden daha az 
uyumsuz olduğu söylenebilir (Treynor vd., 2003). Nolen-Hoeksema, Wisco ve Lyubomirsky (2008), ruminasyonun başa çıkma ve problem çözme becerileri ile negatif yönde ilişkili olduğunu belirtmektedir. Siegle, Moore ve Thase (2004)'e göre ise, ruminasyon bir başa çıkma stratejisidir. Aynı zamanda ruminasyon, aşırı genelleyici düşünme tarzı, düşük bilişsel esneklik ve olumsuz uyaranlara dikkat çekme ile de yakından ilişkilidir (Davis ve Nolen-Hoeksema, 2000).

Zaman yönetiminde sıkıntı yaşayan kişilerin akademik erteleme sorunu ile karşı karşıya kaldıkları çeşitli çalışmalarda görülmüştür (Lay ve Schouwenburg, 1993; Vodanovich ve Seib, 1997). Zaman yönetimi için; kişinin önceliklerini belirleyip amacı doğrultusunda ilerleme, zaman yönetimi teknikleri ve zaman yönetimi için organize olma ve düzenleme olmak üzere üç davranış türü, belirlenmiştir (Macan, 1994). $\mathrm{Bu}$ davranışları akademik erteleme yaşayan kişinin zorlanarak yaptığı, zamanı kontrol etme ve planlamada sorunlar yaşadığı görülmektedir (Macan, 1994). Aynı zamanda bireylerin hayatında beklenmedik şekilde ortaya çıkan durumlar olduğunda ve bununla baş edemeyip kargaşa oluştuğunda, bilişsel esneklik devreye girerek bireylerin duruma uyum sağlamasını kolaylaştırır ve yeni sorun çözme teknikleri geliştirmesine yardımcı olur (Çuhadaroğlu, 2011; 2013). Buğa, Özkamalı, Altunkol-Wise ve Çekiç (2019), üniversite öğrencileri ile yaptıkları çalışmada da, bilişsel esnekliğin arttıkça probleme dair tutumun daha olumlu olduğunu ve daha etkili problem çözme stratejileri geliştirildiğini bulmuşlardır. Bu doğrultuda bireylerin bilişsel esneklikleri arttıkça planlama ve çözüm üretme stratejilerinin geliştiği, eş zamanlı daha fazla göreve odaklanabildikleri, bu sayede de zaman yönetimini daha iyi yapabildikleri ve akademik erteleme davranışlarının azalabileceği düşünülmektedir.

Diğer yandan, başa çıkma ve problem çözme becerileri ile ruminatif düşünme biçimi arasında ve dolayısıyla da erteleme davranışı arasında ilişki olduğu düşünülmektedir. Etkili başa çıkma ve problem çözme becerileri geliştiremeyen bireylerin belirli bir sorunla karşılaştıklarında genellikle sorun üzerine ruminatif düşünme eğiliminde oldukları (Nolen-Hoeksema vd., 2008) ve sorunun çözümü için eyleme geçmek yerine ertelemeyi tercih ettikleri görülmektedir (Bilge, Türk, Bilge ve Deniz, 2015; Lay, Edwards, Parker ve Endler, 1989; Neziroğlu, 2010). Flett, Stainton, Hewitt, Sherry ve Lay (2012) de, ertelemeyi ruminasyonun özel bir biçimi olarak görmekte, stres ve kaygı ile ilişkili olduğunu belirtmektedirler.

Strese neden olan durum veya durumlarla mücadele etme sürecine başa çıkma, strese yönelik kişinin verdiği tepki tarzına ise başa çıkma stratejisi denir (Lazarus, 1966; Lazarus ve Folkman, 1984). Başa çıkma stratejileri, genel olarak problem odaklı ve duygu odaklı olarak sinıflandırılmakla (Lazarus ve Folkman, 1984) birlikte, ayrıca kaçınmacı başa çıkma stratejisinden de sıklıkla bahsedilmektedir (Ebata ve Moos, 1991; Roth ve Cohen, 1986; Van Berkel, 2009). Lazarus ve Folkman (1984)'a göre, duygu odaklı başa çıkmayı kullanan kişi bastırma, yansıtma, mantığa bürünme ve kaçınma gibi savunma mekanizmalarını kullanarak gerçeği olduğundan farklı algılama eğilimi gösterebilir. Kişinin problem üzerinde düşünmesine rağmen, gerçeği olduğundan farklı algılama eğiliminde olması, çözüme yönelik harekete geçmek yerine kaçınmacı başa çıkma stratejisine başvurmasına ve problemin çözümünü ertelemesine neden olmaktadır (Beleaua ve Cocoradă, 2016).

Ruminasyonun ilişkili olduğu bir diğer konu, problem çözme becerisidir. Ruminatif eğilime sahip bireylerin problem çözme becerilerinden yoksun olduğu düşünülmektedir (Lyubomirsky, Tucker, Caldwell, ve Berg, 1999). Esasen ruminatif düşünen bir kişi, etkili çözümler üretse bile, çözümü uygulamada başarısız olur (Neziroğlu, 2010). Bilge, Türk, Bilge ve Deniz (2015), problem çözme ile erteleyici karar verme arasında anlamlı ilişki olduğunu tespit etmiştir. Kişinin problem çözme becerilerini etkili bir şekilde ortaya koyamaması, kendisini yetersiz hissetmesine, problemi çözmek için eyleme geçmek yerine sorunu takıntılı bir biçimde tekrar tekrar düşünmesine ve kararlarını ertelemesine sebep olmaktadır (Bilge, Türk, Bilge ve Deniz, 2015; Neziroğlu, 2010; Stainton, Lay ve Flett, 2000). Erteleme davranışları hakkında ruminatif düşünme, sıkıntıya yatkın bireylerin kendi başarısızlıkları ve yetersizlikleri hakkında çıkarımlarda bulunmalarının bir yoludur (Flett vd., 2012).

Alan yazın tarandığında doğrudan akademik erteleme ile ruminasyon, akademik erteleme ile bilişsel esnekliğin ilişkisi, bilişsel esneklik ve ruminasyon düzeylerinin birlikte akademik ertelemeye olan etkisine dair çalışma olmadığı görülmüştür. Yukarıdaki alan yazın değerlendirildiğinde, bilişsel esneklik yükseldikçe ve ruminasyon azaldıkça zor durumlar içerisinde hızlı plan yapabilme, probleme yönelik çözüm üretebilme ve çözümleri etkili bir şekilde uygulayabilme ve bu doğrultuda sorunlarla etkili bir 
şekilde başa çıkma becerisi kazanarak ve zaman yönetiminde ustalaşarak akademik ertelemeyi azaltmanın mümkün olduğu görülmektedir. Ergenlik döneminde fiziksel, sosyal ve bilișsel alandaki hızlı değişimler, öğrencilerin organize olma, zamanı yönetme, esnek düşünme ve problem çözme becerilerinin ve dolayısıyla akademik alandaki etkinliklerinin olumsuz yönde etkilenmesini beraberinde getirebilmektedir. Lise dönemi, öğrencilerin gelecekteki kariyerlerini ve meslek hayatlarını belirleyecekleri yükseköğretim kademesine hazırlık yaptıkları önemli bir süreç olduğu için öğrencilerin akademik motivasyonunu etkileyecek faktörleri belirlemek ve ona göre önleyici ve geliştirici müdahalelerde bulunmak oldukça önemlidir. $\mathrm{Bu}$ nedenle, bu araştırma liseli ergenler ile gerçekleştirilmiştir. Ruminasyon ve bilişsel esnekliğin problem çözme becerileri ile olan ortak ilişkileri de göz önüne alındığında, lise öğrencilerinin yaşadığı akademik ertelemeyi azaltabilmek için onların ruminatif düşünce tarzları ve bilişsel esnekliklerinin bulunup bulunmadığını belirlemek, bu doğrultuda müdahale programları geliştirmek önem arz etmektedir.

Bu savla hareket edildiğinde, bu araştırmada bilişsel esnekliğin yükselmesi ve ruminatif düşüncelerin azalmasının, akademik ertelemenin azalması noktasında etkisi olup olmadığını tespit etmek amaçlanmıştır. Araştırmadaki bu amaç, şu sorularla değerlendirilmeye alınmıştır:

1. Bilişsel esneklik ve ruminatif düşünceler birlikte akademik ertelemenin ne kadarını yordamaktadır?

2. Bilişsel esneklik ve ruminatif düşünceler ayrı ayrı akademik ertelemenin ne kadarını yordamaktadır?

3. Bilişsel esneklik, ruminatif düşünce ve akademik erteleme arasında ilişki var mıdır?

4. Cinsiyete göre bilişsel esneklik, ruminatif düşünce ve akademik erteleme puanları değişmekte midir?

5. Cinsiyete göre, bilişsel esneklik ve ruminatif düşüncelerin akademik ertelemeyi yordamadaki gücü farklılaşmakta mıdır?

\section{YÖNTEM}

\section{Araştırmanın Modeli}

Araştırmanın modelini ilişkisel tarama modeli oluşturmaktadır. İlişkisel tarama modeli iki veya daha fazla değişkenin birlikte artması, azalması veya bir değişken artarken diğerinin azalması şeklinde değişkenlerin birbirleriyle ilişkilerini göstermektedir (Büyüköztürk, Kılıç-Çakmak, Akgün, Karadeniz ve Demirel, 2014; Böke, 2010). İlişkisel tarama modelini uygulayan araştırmacılar, deneysel araştırmalarda olduğu gibi değişkenleri kontrol altına almaya çalışmadan iki veya daha fazla değişkenin puanları arasında ilişkinin olup olmadığını ortaya koymaktadırlar (Creswell, 2017). Bu araştırma kapsamında da değişkenler arası ilişkiler inceleneceğinden ilişkisel tarama modelinden faydalanılmıştır.

\section{Evren ve Örneklem}

Bu çalışmanın evrenini İstanbul ilindeki liseler oluşturmaktadır. Araştırmanın örneklemi, evreni temsil edilebilirliğinin yüksek olması için İstanbul'un Anadolu ve Avrupa yakasından nüfus olarak kalabalık ve göç alan bölgelerinden olan Beylikdüzü ve Sultanbeyli ilçelerindeki birer imam hatip lisesi olarak belirlenmiştir. Araştırmanın örnekleminde rastgele olmayan yöntemlerden kolayda örnekleme yöntemi kullanılmıştır. Zaman, emek ve maddi yönden tasarruf sağlamasından ötürü bu yöntem seçilmiştir (Marshall, 1996). Çeşitli sosyoekonomik, eğitim ve kültürel düzeylerden bireylerin bulunduğu iki farklı bölgede bulunan ilçenin kullanılmasının çeşitlilik olarak önem arz edeceği düşünülmektedir. İki ayrı liseden toplam 400 veriye ulaşılmış, analizler için yetersiz olanlar ayıklandıktan sonra 297 veri kullanılmıştır. Veriler 2018 yılında toplanmıştır. Araştırmaya katılan öğrencilerin ait demografik bilgileri Tablo 1'de verilmiştir. Bireylerin çeşitli kültürlerden olmaları kişiliğin oluşmasında önemli bir yer tutmaktadır (Ewen, 2003). Cinsiyet de kişilik özelliklerinin oluşmasında rol alan bir faktördür (Çıkrıkçı ve Erzen, 2016). Bu sebeple cinsiyetin bilişsel esneklik, ruminasyon ve akademik erteleme düzeyleri üzerindeki etkisi de bu çalışmada incelenmiştir.

Tablo 1. Araştırmaya Katılan Öğrencilerin Demografik Bilgileri 


\begin{tabular}{llcc}
\hline Tablolar & Gruplar & F & \% \\
\hline Cinsiyet & K1z & 137 & 46.1 \\
\cline { 2 - 4 } & Erkek & 160 & 53.9 \\
\cline { 2 - 4 } & Toplam & 297 & 100.0 \\
\hline \multirow{3}{*}{ Sinıf } & 11. sinif & 177 & 59.6 \\
\cline { 2 - 4 } & 12. sinif & 120 & 40.4 \\
\cline { 2 - 4 } & Toplam & 297 & 100.0 \\
\hline
\end{tabular}

Tablo 1'de görüldüğü üzere, örneklemi oluşturan lise öğrencilerinin 137'sini (\%46.1) kız öğrenciler; 160'ını (\%53.9) ise erkekler oluşturmaktadır. Öğrencilerden 177'si (\%59.6) 11. sınıf, 120'si (\%40.4) 12. sınıfta öğrenim görmektedirler.

\section{Veri Toplama Araçları}

Akademik Erteleme Ölçeği: Akademik erteleme ölçeği, Çakıcı (2003) tarafından geliştirilmiştir. Ölçek, 19 madde ve iki faktörden oluşmakta olup, beşli likert tipi bir ölçektir. Faktörlerden biri erteleme, diğeri düzenli ders çalışma alışkanlığıdır. Ölçeğin Cronbach Alpha güvenirlik katsayısı .92 olarak bulunmuştur. Ölçeğin birinci faktörü için hesaplanan Cronbach Alpha güvenirlik katsayısı .89; ikinci faktör için hesaplanan Cronbach Alpha güvenirlik katsayısı .84'tür. Sperman Brown iki yarım test güvenirliği, 10 maddelik birinci yarım test için $.87,9$ maddelik ikinci yarım test için .86 olmak üzere toplam .85 olarak hesaplanmıştır. Test tekrar test korelasyon katsayısı .89 olarak bulunmuştur. Ölçeğin test tekrar test güvenirlik katsayısı 1. faktör için .80, 2. faktör için ise .82 olarak hesaplanmıştır (Çakıcı, 2003). Bu çalışmada ise akademik erteleme ölçeğinin yalnızca erteleme alt boyutu kullanılmıştır.

Bilişsel Esneklik Ölçeği (BEÖ): Martin ve Rubin (1995) tarafindan geliştirilen BEÖ’nün geçerlik ve güvenirlik çalışmaları Çelikkaleli (2014) tarafından gerçekleştirilmiştir. Buna göre orijinali 12 maddeden oluşan ölçeğin 11 maddelik Türkçe formunun AFA sonucunda elde edilen tek boyutlu yapısı DFA ile elde edilen yapıyla uyum göstermektedir. 6'lı Likert tipi bir ölçme aracı olan BEÖ 1 "kesinlikle katılmıyorum" 6 "kesinlikle katılıyorum" biçiminde cevaplandırılmaktadır. Güvenirlik çalışmalarında üç farklı örneklemde iç tutarlık katsayıları sırasıyla .74, .73 ve .75 olarak elde edilmiştir. Ölçeğin iki yarı güvenirliği için sırasıyla elde edilen katsayı ise tüm örneklemlerde .77'dir. Ayrıca test-tekrar test güvenirlik çalışmasında iki uygulama arasında .98 'lik bir korelasyon elde edilmiştir. Dil geçerliği çalışmasında orijinal İngilizce form ile Türkçe form arasında .88'lik bir korelasyon elde edilmiştir. Ölçüt bağıntılı geçerlik çalışmasında BEÖ ile Problem Çözme Envanteri'nin Problem Çözmeye Güven ve Kişisel Kontrol arasında pozitif yönde; Yaklaşma-Kaçınma arasında negatif yönde anlamlı bir ilişki elde edilmiştir.

Ruminasyon Ölçeği, Kısa Formu (RÖ): Bireylerin ruminatif başa çıkma biçimini ne derece kullandığını değerlendiren 21 maddelik uzun formdaki ölçekten (Nolen-Hoeksema ve Morrow, 1991) depresif belirtilerle örtüştüğü eleştirisine maruz kalan maddelerin çıkarılmasıyla oluşturulmuş kısa RÖ, 1-4 arası puanlanan Likert tipi 10 maddeden oluşmaktadır (Treynor vd., 2003). Erdur-Baker ve Bugay (2012) tarafindan Türkçeye uyarlanmıştır. Saplantılı düşünme ve derin düşünme olmak üzere 2 alt boyuttan oluşan Ruminasyon Ölçeği (RÖ) kısa formunun iyi derecede güvenilirlik (Cronbach $\alpha=.85$ ) ve geçerlik (BDE ile $r=.60$ ) değerlerine sahip olduğu rapor edilmiştir (Erdur-Baker ve Bugay 2012).

\section{Verilerin Analizi}

Araştırmada veri toplama araçları ile elde edilen veriler, SPSS 21.00 programı kullanılarak analiz edilmiştir. İlk olarak, değişkenlerin betimleyici istatistikleri ve güvenirlik katsayıları incelenmiştir. Ardından cinsiyete göre ‘Bağımsız Gruplar t Testi' ve değişkenler arası ilişkiyi incelemek için 'Pearson Momentler Çarpımı Korelasyon Tekniği' analizi yapılmıştır. Daha sonra, bilişsel esneklik ve ruminasyonun akademik ertelemeyi yordayıp yordamadığı 'Çoklu Aşamalı Regresyon Analizi' ile gerçekleştirilmiştir. Araştırmada, anlamlılık düzeyi .05 olarak kabul edilmiştir.

\section{BULGULAR}


$\mathrm{Bu}$ bölümde, öncelikle fark analizleri sonucunda elde edilen bulgulara, sonra akademik erteleme ile bilişsel esneklik ve ruminasyon arasındaki ilişkinin belirlenmesine yönelik yapılan analiz sonuçlarına ve regresyon işlemi için verilerin uygunluğu belirlendikten sonra ise, araştırmanın amacına yönelik olarak yapılan regresyon analizi sonuçlarına yer verilmiştir.

Tablo 2. Katılımcıların Bilişsel Esneklik, Ruminasyon ve Akademik Erteleme Puanlarının Cinsiyete Göre Farklılaşıı Farklılaşmadığına İlişkin Bă̆ımsız Gruplar t Testi Sonuçları

\begin{tabular}{|c|c|c|c|c|c|c|c|c|c|}
\hline \multirow[b]{2}{*}{ Puan } & \multirow[b]{2}{*}{ Gruplar } & \multirow{2}{*}{ 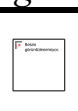 } & \multirow{2}{*}{ 阔 } & \multirow[b]{2}{*}{$=$} & \multirow{2}{*}{-} & \multicolumn{3}{|c|}{ Testi } & \multirow{2}{*}{$\begin{array}{l}\text { Etki değeri } \\
\text { (Cohen's } d) \\
\end{array}$} \\
\hline & & & & & & $=$ & & $\because$ & \\
\hline \multirow{2}{*}{$\begin{array}{l}\text { Bilişsel } \\
\text { Esneklik }\end{array}$} & Erkek & 160 & 50.53 & 8.05 & .63 & \multirow{2}{*}{2.47} & \multirow{2}{*}{295} & \multirow{2}{*}{.014} & \multirow{2}{*}{.288} \\
\hline & $\mathrm{K}_{1 \mathrm{Z}}$ & 137 & 52.80 & 7.69 & .65 & & & & \\
\hline \multirow{2}{*}{ Ruminasyon } & Erkek & 160 & 23.44 & 5.32 & .42 & \multirow{2}{*}{1.35} & \multirow{2}{*}{256.57} & \multirow{2}{*}{.178} & \multirow{2}{*}{.159} \\
\hline & $\mathrm{K}_{1 \mathrm{Z}}$ & 137 & 24.41 & 6.77 & .57 & & & & \\
\hline \multirow{2}{*}{$\begin{array}{l}\text { Akademik } \\
\text { Erteleme }\end{array}$} & Erkek & 160 & 35.68 & 8.66 & .68 & \multirow{2}{*}{-1.92} & \multirow{2}{*}{295} & \multirow{2}{*}{.055} & \multirow{2}{*}{.224} \\
\hline & Kiz & 137 & 33.68 & 9.21 & .78 & & & & \\
\hline
\end{tabular}

Tablo 2'de görüldüğü gibi, örneklem grubunu oluşturan lise öğrencilerinin bilişsel esneklik, ruminasyon ve akademik erteleme puanlarının cinsiyet değişkenine göre anlamlı bir farklılık gösterip göstermediğini belirlemek amacıyla yapılan bağımsız grup t testi sonucunda grupların bilişsel esneklik aritmetik ortalamaları arasında anlamlı bir farklılık bulunmuştur ( $\mathrm{t}_{\text {bililselesneklik }}=2.47 ; p<.05$ ). Etki büyüklüğ̈̈ (Cohen's $d$ ) değeri ise 0.288 olarak hesaplanmıştır. Cohen (1988)'in sınıflandırmasına göre, bu değer zayıf (düşük) etki büyüklüğü aralığında yer almaktadır. Dolayısıyla, kız ve erkek öğrencilerin bilişsel esneklik puanları arasında düşük düzeyde etki değeri olan anlamlı bir farklılık olduğu söylenebilir. Tablodan da anlaşılacağı üzere bilişsel esneklik ölçeğindeki farklılık kız öğrenciler lehinedir Bu durum kız öğrencilerin bilişsel esneklik düzeylerinin erkek öğrencilere göre daha fazla olduğunu göstermektedir. Cinsiyete göre ruminasyon ve akademik erteleme aritmetik ortalamaları arasında ise anlamlı bir farklılık bulunmamıştır.

Tablo 3. Bilişsel Esneklik, Ruminasyon ve Akademik Erteleme Ölçekleri Güvenirlik Katsayıları

\begin{tabular}{ll}
\hline Değişken & Cronbach's Alpha Değeri \\
\hline Bilişsel Esneklik & .732 \\
\hline Ruminasyon & .813 \\
\hline Akademik Erteleme & .797 \\
\hline
\end{tabular}

Tablo 3 incelendiğinde, bilişsel esneklik, ruminasyon ve akademik erteleme ölçekleri için bulunan Cronbach's alpha katsayıları sırasıyla; bilişsel esneklik ölçeği için .73; ruminasyon için .81; akademik erteleme ölçeği içinse .80 olarak bulunmuştur. Üç ölçeğe ait güvenirlik katsayısının da .70 'in üzerinde bir değere sahip olduğu görülmektedir. Yaygın olarak kabul edilen yaklaşıma göre, elde edilen bu değerler ölçeklerin iyi güvenirliğe sahip olduğunu göstermektedir (Kılıç, 2016).

Tablo 4. Araştırma Değiş̧kenlerine Ait Ortalama, Standart Sapma ve Korelasyon Değerleri $(N=297)$

\begin{tabular}{lccccc}
\hline Değişkenler & Ort. & $\boldsymbol{S}$ & $\mathbf{1}$ & $\mathbf{2}$ & $\mathbf{3}$ \\
\hline 1. Akademik Erteleme & 34.76 & 7.95 & 1.00 & & \\
2. Bilişsel Esneklik & 51.58 & 8.96 & $-.301^{* *}$ & 1.00 & \\
3. Ruminasyon & 23.90 & 6.05 & $.161^{*}$ & $-.132^{*}$ & 1.00 \\
\hline
\end{tabular}

${ }^{*} p<.05,{ }^{* *} p<.001$

Tablo 4 incelendiğinde, araştırmaya dâhil edilen değişkenlere ait ortalama değerler, standart sapma değerleri ve Pearson korelasyon katsayıları görülmektedir. Pearson korelasyon katsayısı analizi sonuçlarına göre, akademik erteleme değişkeninin, bilişsel esneklik $(r=-.30, p<.001)$ ile negatif yönde ilişkili olduğu; ruminasyon değişkeni $(\mathrm{r}=.16, p<.05)$ ile pozitif yönde ilişkili olduğu bulunmuştur. Bilişsel esneklik ile ruminasyon arasındaki ilişkinin ise $(r=-.13, p<.05)$ negatif yönde anlamlı olduğu tespit edilmiştir. Bu sonuç, bilişsel esneklik arttıkça akademik ertelemenin azalacağı, ruminasyon 
arttıkça ise akademik ertelemenin artacağını göstermektedir. Cohen (1988)'in $r$ değeri sınıflandırmasına göre, .10 küçük bir ilişkiyi, .30 orta bir ilişkiyi, .50 ve üzeri ise büyük bir ilişkiyi ifade etmektedir. $\mathrm{Bu}$ doğrultuda elde edilen bulgulara göre, değişkenler arasındaki ilişkilerin küçük ve orta düzeyde olduğu görülmektedir.

Tablo 4.1. Kız Öğrencilerin Akademik Erteleme, Bilişsel Esneklik ve Ruminasyon Puanlarına Ait Ortalama, Standart Sapma ve Korelasyon Değerleri $(N=137)$

\begin{tabular}{lccccc}
\hline Değişkenler & Ort. & $\boldsymbol{S}$ & $\mathbf{1}$ & $\mathbf{2}$ & $\mathbf{3}$ \\
\hline 1. Akademik Erteleme & 33.68 & 9.22 & 1.00 & & \\
2. Bilişsel Esneklik & 52.79 & 7.70 & $-.337^{* *}$ & 1.00 & \\
3. Ruminasyon & 24.42 & 6.77 & .148 & $-.244^{*}$ & 1.00 \\
\hline
\end{tabular}

${ }^{*} p<.05,{ }^{* *} p<.001$

Tablo 4.1 incelendiğinde, araştırmaya katılan kız öğrencilerin akademik erteleme, bilişsel esneklik ve ruminasyon puanlarına ait ortalama değerler, standart sapma değerleri ve Pearson korelasyon katsayıları görülmektedir. Pearson korelasyon katsayısı analizi sonuçlarına göre, kız öğrencilerin akademik erteleme puanlarının, bilişsel esneklik $(r=-.34, p<.001)$ ile negatif yönde ilişkili olduğu bulunmuş; akademik erteleme ile ruminasyon değişkeni arasındaki ilişki ise anlamlı bulunmamıştır $(\mathrm{r}=.15, p>.05)$. Bilişsel esneklik ile ruminasyon arasındaki ilişkinin ise $(r=-.24, p<.05)$ negatif yönde anlamlı olduğu tespit edilmiştir.

Tablo 4.2. Erkek Öğrencilerin Akademik Erteleme, Bilişsel Esneklik ve Ruminasyon Puanlarına Ait Ortalama, Standart Sapma ve Korelasyon Değerleri $(N=160)$

\begin{tabular}{lccccc}
\hline Değişkenler & Ort. & $\boldsymbol{S}$ & $\mathbf{1}$ & $\mathbf{2}$ & $\mathbf{3}$ \\
\hline 1. Akademik Erteleme & 35.69 & 8.66 & 1.00 & & \\
2. Bilişsel Esneklik & 50.54 & 8.04 & $-.249^{*}$ & 1.00 & \\
3. Ruminasyon & 23.46 & 5.33 & $.201^{*}$ & -.046 & 1.00 \\
\hline${ }^{*} p<.05,{ }^{* * *} p<.001$ & & & & &
\end{tabular}

Tablo 4.2 incelendiğinde, araştırmaya katılan erkek öğrencilerin akademik erteleme, bilişsel esneklik ve ruminasyon puanlarına ait ortalama değerler, standart sapma değerleri ve Pearson korelasyon katsayıları görülmektedir. Pearson korelasyon katsayısı analizi sonuçlarına göre, erkek öğrencilerin akademik erteleme puanlarının, bilişsel esneklik $(r=-.25, p<.05)$ ile negatif yönde; ruminasyon $(\mathrm{r}=.20, p<.05)$ ile pozitif yönde anlamlı ilişkiye sahip olduğu tespit edilmiştir. Bilişsel esneklik ile ruminasyon arasındaki ilişki ise anlamlı bulunmamıştır $(r=-.05, p>.05)$.

Kız ve erkek öğrenciler için ayrı ayrı incelenen korelasyon analizi sonuçlarına göre, kız öğrencilerin akademik erteleme ve bilişsel esneklik puanları arasındaki ilişki, erkek öğrencilerin akademik erteleme ve bilişsel esneklik puanları arasındaki ilişkiden daha yüksektir. Kız öğrencilerin akademik erteleme ve ruminasyon puanları arasındaki ilişki anlamlı değilken, erkek öğrencilerin akademik erteleme ve ruminasyon puanları arasındaki ilişki anlamlıdır. Diğer yandan, kız öğrencilerin bilişsel esneklik ile ruminasyon puanları arasındaki ilişki anlamlı iken, erkek öğrencilerin bilişsel esneklik ile ruminasyon puanları arasındaki ilişki anlamlı değildir.

Tablo 5. Bilişsel Esneklik ve Ruminasyonun Akademik Ertelemeyi Yordamasına İlişkin Çoklu Regresyon Analizi Tablosu $(N=297)$

\begin{tabular}{lcccccccc}
\hline & $B$ & $\begin{array}{l}\text { Standart } \\
\text { Hata }\end{array}$ & Beta & $t$ & Sig & $R^{2}$ & $F$ & Sig \\
\hline Bilişsel & -.321 & .063 & -.284 & -5.111 & .000 & .106 & 17.340 & .000 \\
Esneklik & .183 & .082 & .124 & 2.225 & .027 & & & \\
Ruminasyon & .182 & & & & & & &
\end{tabular}


Tablo 5 incelendiğinde, akademik erteleme düzeyini yordamada bilişsel esneklik ve ruminasyon değişkenlerinin rolünü saptamak amacıyla yapılan çoklu regresyon analizinde, bu değişkenlerin akademik ertelemeyi anlamlı bir şekilde yordadığı görülmektedir $\left(F=17.340, p<.001, R=.325, R^{2}=\right.$ $.106, \operatorname{adj} R=.099$ ). Analiz sonuçlarına göre, bilişsel esneklik ve ruminasyon değişkenleri ikisi birlikte, akademik ertelemedeki toplam varyansın yaklaşık \%11'ini açıklamaktadır. Bilişsel esneklik değişkeninin varyansa katkısı anlamlı $(\beta=-.284, t=-5.11, p<.001)$ bulunduğu gibi, ruminasyon değişkeninin de varyansa katkısı anlamlı $(\beta=.124, t=2.23, p<.05)$ bulunmuştur.

Tablo 5.1. Kız Öğrencilerin Bilişsel Esneklik ve Ruminasyon Puanlarının Akademik Ertelemeyi Yordamasına İlişkin Çoklu Regresyon Analiz Tablosu $(N=137)$

\begin{tabular}{lcccccccc}
\hline & $B$ & $\begin{array}{l}\text { Standart } \\
\text { Hata }\end{array}$ & Beta & $t$ & Sig & $R^{2}$ & $F$ & Sig \\
\hline Bilişsel & -.384 & .100 & -.320 & -3.831 & .000 & .118 & 8.995 & .000 \\
Esneklik & .095 & .114 & .070 & .832 & .407 & & & \\
Ruminasyon & .095 &
\end{tabular}

Tablo 5.1 incelendiğinde, kız öğrencilerin akademik erteleme düzeyini yordamada bilişsel esneklik ve ruminasyon değişkenlerinin rolünü saptamak amacıyla yapılan çoklu regresyon analizinde, bu değişkenlerin akademik ertelemeyi anlamlı bir şekilde yordadığı görülmektedir $(F=8.995, p<.001, R=$ $.344, R^{2}=.118$, adj $R=.105$ ). Analiz sonuçlarına göre, kız öğrencilerin bilişsel esneklik ve ruminasyon puanları ikisi birlikte, akademik ertelemedeki toplam varyansın yaklaşık \%12'sini açıklamaktadır. Bilişsel esneklik değişkeninin varyansa katkısı anlamlı $(\beta=-.320, t=-3.83, p<.001)$ bulunurken; ruminasyon değişkeninin varyansa katkısı anlamlı $(\beta=.070, t=.832, p>.05)$ bulunmamıştır.

Tablo 5.2. Erkek Öğrencilerin Bilişsel Esneklik ve Ruminasyon Puanlarının Akademik Ertelemeyi Yordamasina İlişkin Çoklu Regresyon Analiz Tablosu $(N=160)$

\begin{tabular}{lllllllll}
\hline & $B$ & $\begin{array}{l}\text { Standart } \\
\text { Hata }\end{array}$ & Beta & $t$ & Sig & $R^{2}$ & $F$ & Sig \\
\hline Bilişsel & -.259 & .082 & -.240 & -3.164 & .002 & .098 & 8.538 & .000 \\
Esneklik & .309 & .123 & .190 & 2.509 & .013 & & & \\
Ruminasyon & .309 \\
\hline
\end{tabular}

Tablo 5.2 incelendiğinde, erkek öğrencilerin akademik erteleme düzeyini yordamada bilişsel esneklik ve ruminasyon değişkenlerinin rolünü saptamak amacıyla yapılan çoklu regresyon analizinde, bu değiş̧kenlerin akademik ertelemeyi anlamlı bir şekilde yordadığı görülmektedir $(F=8,538, p<.001, R$ $=.313, R^{2}=.098$, adj $\left.R=.087\right)$. Analiz sonuçlarına göre, erkek öğrencilerin bilişsel esneklik ve ruminasyon puanları ikisi birlikte, akademik ertelemedeki toplam varyansın yaklaşık \%10'unu açıklamaktadır. Bilişsel esneklik değişkeninin varyansa katkısı anlamlı $(\beta=-.240, t=-3.164, p<.05)$ bulunduğu gibi; ruminasyon değişkeninin varyansa katkısı da anlamlı $(\beta=.190, t=2.509, p<.05)$ bulunmuştur.

Kız ve erkek öğrenciler için ayrı ayrı incelenen regresyon analizi sonuçlarına göre, kız öğrencilerin bilişsel esneklik ve ruminasyon puanları ikisi birlikte, akademik erteleme puanlarını \%12 düzeyinde açıklarken, erkek öğrencilerin bilişsel esneklik ve ruminasyon puanları ikisi birlikte, akademik erteleme puanlarını \%10 düzeyinde açıklamaktadır.

\section{TARTIŞMA}

Lise öğrencilerinin akademik erteleme davranışlarının bilişsel esneklik ve ruminasyonla ilişkisinin incelendiği bu çalışmada, erteleme davranışı gösteren kız ve erkek öğrencilerin bilişsel esnekliklerinin ve ruminasyon düzeylerinin bu durumu etkilediği görülmektedir. Araştırma sonucunda, akademik erteleme düzeyi arttıkça bilişsel esneklik düzeyinin azaldığı ortaya çıkmıştır. Akademik ertelemenin düşük öz yeterlilik ve kaçınmacı problem çözme davranışları ile ilişkili olduğuna dair çalışmalar 
bulunmaktadır (Bridges ve Roig, 1997; Corkin, Yu, Wolters ve Wiesner, 2014). Liseli ergenler üzerinde yapılan bir çalışmada bilişsel esnekliğin akademik sosyal ve duygusal öz yeterlikle ilişkisi incelenmiştir. Araştırma sonucu öz yeterlik ve bilişsel esneklik arasında anlamlı bir ilişki bulunmuştur. Bu araştırmalar bize öz yeterlik inancına sahip kişilerin bilişsel esnekliklerinin yüksek, akademik ertelemelerinin düşük olduğunu göstermektedir. Bu doğrultuda yapılan araştırmanın literatürle uyumlu sonuçlar ortaya çıkardığı görülmektedir.

Ayrıca araştırmanın bir diğer sonucu, ruminasyon düzeyi arttıkça akademik erteleme davranışlarının arttığını göstermektedir. Ruminasyon eğilimi gösteren kişilerin davranışları incelendiğinde, sorunu gözünde büyütme, kabullenmeme (yadsıma), etkili başa çıkamama, planlama ve problem çözme becerilerinden yoksun olma, kendi içine kapanma, problem çözümü için eyleme geçmede zorlanma eğiliminde olduğu görülmektedir (Aldao, Nolen-Hoeksema ve Schweizer, 2010; Lyubomirsky vd., 1999; Nolen-Hoeksema vd., 2008). Ruminatif eğilimlere yol açan bu davranışların kişinin erteleme davranış1 göstermesine de yol açacağı düşünülmektedir. Halihazırda var olan araştırmalar incelendiğinde de ruminasyonun başa çıkma stratejileri ve problem çözme becerileri ile ilişkili olduğu görülmektedir (Neziroğlu, 2010; Nolen-Hoeksema vd., 2008; Siegle vd., 2004). Bu çalışmalar, kaçınmacı başa çıkma stratejilerine sahip bireylerin var olan durumu kabul etmek yerine görmezden gelme eğiliminde olduğunu, planlama yapmak ve destek aramak yerine ilgiyi kesme ve gayret göstermeme eğilimde olduğunu göstermektedir (Ebata ve Moos, 1991; Roth ve Cohen, 1986). Bu davranışların da kişinin harekete geçmesine engel olacağı ve erteleme davranışına yol açacağ düşünülmektedir. Ruminatif eğilime sahip kişiler, karşılaş̧ıkları sorunla veya stres verici bir durumla etkili bir şekilde baş etmeye çalışmak yerine kaçınma davranışları gösterme eğilimdedir ki bu da erteleme davranışlarına yol açmaktadır (Beleaua ve Cocoradă, 2016; Burns, Dittmann, Nguyen ve Mitchelson, 2000). Gareau, Chamandy, Kljajic ve Gaudreau (2018) da, erteleme ve başarı arasındaki ilişkide başa çıkmanın oldukça önemli bir rol oynadığını tespit etmiştir. Duygu odaklı ve kaçınmacı başa çıkma stratejilerinin, stres verici sınav durumlarında görülen kaygının pozitif yönde anlamlı bir yordayıcısı olduğu, kaygının erteleme davranışını doğurduğu ve bunun da akademik performansı ve dolayısıyla başarıyı olumsuz etkilediği düşünülmektedir (Endler, Kantor ve Parker, 1994). Bu doğrultuda, bu araştırmada elde edilen ruminasyon arttığında akademik ertelemenin de arttığ bulgusunun literatürle uyumlu olduğu görülmektedir.

Akademik ertelemeye yol açan diğer sebepler ise stres ve kaygıdır (Akdoğan, 2013; Kandemir, 2014; Scher ve Osterman, 2002). Kişide stres ve kaygı düzeyi arttıkça akademik erteleme gösterme düzeyi artmaktadır. Altunkol'un (2011) çalışmasında da bilişsel esneklik düzeyleri yüksek bireylerin stres düzeylerinin düşük olduğu bulunmuştur. $\mathrm{Bu}$ durum stres ve kaygı düzeyinin arttıkça akademik ertelemenin arttığı ve bilişsel esnekliğin azaldığını göstermektedir. Araştırmalar ruminasyonun da stres, kayg1, depresyon gibi çeşitli psikolojik sorunlar ile ilişkili olduğunu göstermektedir (Bugay ve ErdurBaker, 2011; Kaya-Kızılöz, 2018; Nolen-Hoeksema, 1991, 2000). Buna göre, kişinin ruminasyon düzeyi arttıkça, stres ve kaygı düzeyinin ve depresif belirtilerin artacağı ve bunun da akademik erteleme davranışına neden olacağı düşünülmektedir.

Kız ve erkek öğrenciler için ayrı ayrı incelendiğinde, kız öğrencilerin akademik erteleme ve bilişsel esneklik puanları arasındaki ilişki, erkek öğrencilerin akademik erteleme ve bilişsel esneklik puanları arasındaki ilişkiden daha yüksektir. Bilişsel esneklik puanlarına bakıldığında da kız öğrencilerin puanlarının erkek öğrencilerden daha yüksek olduğu görülmektedir. Bilişsel esnekliğin cinsiyete göre farklılaşıp farklılaşmadığına dair literatürde çeşitli sonuçlar yer almaktadır. Araştırmaların çoğunda cinsiyet ve bilişsel esneklik arasında anlamlı bir farklılık bulunmamıştır (Anayurt, 2017; Bilgiç, 2015; Çelikkaleli, 2014; Çuhadaroğlu, 2011; Diril, 2011; Doğan-Laçin, 2015; Martin ve Rubin, 1995; Öz, 2012; Zong ve ark., 2010). Bununla beraber bilişsel esnekliğin cinsiyete göre değiştiğini ortaya koyan çalışmalar da bulunmaktadır (Altunkol, 2011; Asıcı ve İkiz, 2015; Kömür, 2018). Altunkol (2011), çalışmasında bilişsel esneklik ve algılanan stres arasındaki ilişki ve bu değişkenlerin cinsiyet, yaş ve sosyo-ekonomik seviyeye göre farklılaşıp farklılaşmadığını 484 üniversite öğrencisi üzerinde incelemiştir. Çıkan sonuca göre erkek öğrencilerin bilişsel esneklik düzeylerinin kız öğrencilerden anlamlı şekilde yüksek olduğu görülmüştür. Asıcı ve İkiz (2015), yaptıkları çalışmada bilişsel esnekliğin kontrol alt boyutunun erkeklerin lehine değiştiğini bulmuştur. Kömür (2018), 200 üniversite öğrencisinin bilişsel esneklik ve stresle başa çıkma becerileri arasındaki ilişkiyi değerlendirdiği 
çalışmasında, bilişsel esneklik kontrol alt boyut puanlarının erkek öğrenciler lehine anlamlı şekilde değiştiğini ortaya koymuştur. $\mathrm{Bu}$ araştırmada literatürden farklı sonuç çıkmasının bazı sebepleri olabilir. Göç alan farklı sosyo-ekonomik, eğitim ve kültürel düzeylerden oluşan İstanbul'un iki ayrı ilçesinde bulunan lise öğrencileri örneklem grubunu oluşturmaktadır. Martin ve Anderson'a (1998) göre, bilişsel esneklik yeniliklere uyum sağlama noktasında istekli olmaktır ve karmaşı yaşam koşulları bilişsel esnekliği arttırmaktadır. Farklı şehirlerden gelen ve İstanbul gibi zor yaşam koşullarının olduğu bir şehre uyum sağlamaya çalışan aileler kız çocuklarını kendi yetiştirildikleri görüşlerden farklı şekilde 21.yüzyıla uygun, eğitim alan, ileride çalışıp daha bağımsız ve özgür olacakları, zor koşullara uyum sağlayacakları şekilde yetiştirmek isteyebilirler. Çocukluk yaşantıları, sosyal çevre gibi faktörlerden etkilenen bilişsel esneklik düzeyi, kız öğrencilerde bu sebepten ötürü daha yüksek çıkmış olabilir. Bu doğrultuda zorlu yaşam koşulları sonucunda alternatif çözüm üretebilen, strateji geliştirebilen öğrenciler, planlama ve zaman yönetimini daha iyi düzeyde yaparak erteleme davranışına daha az başvurmaktadırlar.

Öğrencilerin ruminasyon puanları incelendiğinde, araştırma sonucuna göre kız ve erkek öğrencilerin ruminasyon puanları arasında anlamlı bir farklılık bulunmamıştır. Literatür incelendiğinde, araştırma sonuçlarının çeşitlilik gösterdiği görülmüştür. Elde edilen sonucu destekleyen araştırmalar olmakla birlikte (Anayurt, 2017; Broderick ve Korteland, 2004; Carter vd., 2009), k1z öğrencilerin erkeklere göre daha çok ruminasyon eğilimine sahip olduğunu gösteren araştırmalar da mevcuttur (Bugay ve ErdurBaker, 2011; Erdur-Baker, 2009; Jose ve Brown, 2008; Neziroğlu, 2010; Treynor vd., 2003). Diğer yandan ayrı ayrı kız ve erkek öğrencilerin akademik erteleme ve ruminasyon puanları arasındaki ilişki incelendiğinde ise, kız öğrencilerin akademik erteleme ve ruminasyon puanları arasında anlamlı bir ilişkiye rastlanmazken, erkek öğrencilerin akademik erteleme ve ruminasyon puanları arasındaki ilişki anlamlı bulunmuştur. Zaten kız öğrencilerin bilişsel esneklik ve ruminasyon puanlarının akademik erteleme üzerindeki etkisini incelemek üzere yapılan regresyon analizinde de bilişsel esneklik ve ruminasyon puanları ikisi birlikte, akademik ertelemedeki toplam varyansın yaklaşık \%12'sini açıklamasına rağmen ruminasyon değişkeninin varyansa katkısı anlamlı bulunmamıştır. Bu bulgulardan hareketle, araştırma sonuçlarının birbiri ile tutarlı olduğu söylenebilir.

Çalışmanın bir diğer sonucu da bilişsel esneklik ile ruminasyon arasında negatif yönde anlamlı bir ilişki olduğudur. Bununla ilgili alan yazın tarandığında ruminasyon ve bilişsel esneklik arasında ilişki olduğu görülmektedir (Genet, Malooly ve Siemer, 2013; Owens ve Derakshan, 2013). Diğer yandan ayrı ayrı kız ve erkek öğrencilerin bilişsel esneklik ve ruminasyon puanları arasındaki ilişki incelendiğinde ise, kız öğrencilerin bilişsel esneklik ve ruminasyon puanları arasındaki ilişki anlamlı bulunmasına rağmen, erkek öğrencilerin akademik erteleme ve ruminasyon puanları arasındaki ilişkinin anlamlı olmadığı görülmüştür. Erkek öğrencilerin akademik erteleme ve ruminasyon puanları arasında ilişki olmaması, k1z ve erkek öğrencilerin birlikte akademik erteleme ve ruminasyon puanları arasındaki ilişkiyi düşürmektedir. Ruminatif düşünceleri olan bireylerin bilişsel esnekliklerinin olmadığı ortaya çıkmıştır (Genet, Malooly ve Siemer, 2013). Anayurt (2017), üniversite öğrencileri ile yaptığı çalışmada bilişsel esnekliğin bazı alt boyutlarının ruminasyonun bazı alt boyutlarını yordadığını bulmuştur. Aynı çalışmada bilişsel esnekliğin bir özelliği olan zor yaşam koşullarını kontrol edilebilir olarak algılayan öğrencilerin, ruminasyonun özellikleri olan saplantılı ve derin düşünme seviyelerinin azaldığı görülmüştür. Martin, Oren ve Boone'da (1991), benzer şekilde bilişsel açıdan esnek olamayan kişilerin sadece kendi sorunlarına yönelerek ruminatif düşünme eğilimlerinin arttığını ifade etmektedir.

Tüm bu sonuçlar incelendiğinde, akademik ertelemenin birçok yordayıcısı bulunmakla beraber bilişsel esneklik ve ruminasyonun da göz ardı edilmemesi gerektiği düşünülmektedir. Özellikle üniversite sınavına hazırlanma, akademik olarak geleceğe yönelik karar alma ve plan yapma sürecinde olan lise dönemindeki ergenlerin, bilişsel esneklikten yoksun olmasının ve ruminatif düşünme eğilimine sahip olmasının akademik olarak erteleme davranışı göstermelerine neden olduğu göz önüne alındığında, liseli ergenler ile gerçekleştirilen bu araştırmanın özellikle okullarda psikolojik danışma ve önleyici rehberlik hizmetleri açısından alana katkı sağlaması beklenmektedir. Okullarda psikolojik danışmanlık birimlerinde akademik erteleme ile başvuran öğrencilerin sorunları için sadece zaman yönetimi ve sorumluluk bilinci veya akılcı olmayan düşüncelerle çalışmak yeterli olmayabilir. Öğrencilerle bilişsel esnekliğin geliştirilmesi ve ruminasyon eğiliminin azaltılması üzerine çalış1lırsa akademik ertelemenin de bu doğrultuda azalacağı düşünülmektedir. Aynı şekilde akademik erteleme sorunu olan kişilerle 
bireysel psikoterapi ve psikolojik danışmanlık yapıldığında da, buna yol açan anksiyete, depresyon gibi değişkenlerle beraber bilişsel esneklik üzerine de çeşitli teknikler uygulanır ve ruminatif tepkiler veren bireylere etkili problem çözme ve baş etme becerileri kazandırılırsa daha hızlı sonuç alınabileceği düşünülmektedir.

Yapılan araştırmanın örnekleminin sadece İstanbul ilinden iki ayrı meslek lisesinden alınmasının araştırmanın sınırlılığı olduğu düşünülmektedir. Bundan sonraki çalışmalarda Anadolu lisesi, Fen lisesi vb farklı lise türlerini, hatta üniversite öğrencilerini de içerecek şekilde daha geniş örneklem kullanılarak tekrar edilmesi daha faydalı olacaktır. Bilişsel esnekliğin nöropsikolojik değerlendirme yardımı ile ölçülmesi ve diğer değişkenlerle ilişkisinin ele alınmasının da ilerdeki çalışmalar açısından daha kapsayıcı olacaktır. Dolayısıyla ergen ve genç yetişkinlerin görünürde yaşadıkları akademik erteleme sorunlarını yordayan bilişsel esnekliğin geliştirilebilmesi için yürütücü işlevleri de içeren çeşitli uygulamalar gerçekleştirilerek doğrudan çözüme ulaşmaları sağlanabilir.

Bilgilendirme / Acknowledgement:

Yazarlar aşağıdaki bilgillendirmeleri yapmaktadırlar:

1- Araşırımacıların katkı oranı eşittir.

2- Bu çalışma, 24-27 Ekim 2019 tarihinde 21. Uluslararası PDR Kongresi'nde sözlü bildiri olarak sunulmuş bildirinin genişletilmiş halidir.

3- Makalenin yazarları arasında çıkar çatışması bulunmamaktadır.

4- Makalemizde araştırma verileri 2018 yllında toplanmıştır. Makaledeki ölçekler için gerekli izin alınmıştır.

5- Bu makalede araştırma ve yayın etiğine uyulmuştur.

\section{KAYNAKÇA}

Abdi Zarrin, S., Gracia, E., \& Paixão, M. P. (2020). Prediction of academic procrastination by fear of failure and self-regulation. Educational Sciences: Theory and Practice, 20(3), 34-43. http://dx.doi.org/10.12738/jestp.2020.3.003

Akdoğan, A. (2013). Farklı depresyon anksiyete stres düzeylerine sahip üniversite ögrencilerinin akademik erteleme davranışlarının incelenmesi. Yayımlanmamış yüksek lisans tezi, Necmettin Erbakan Üniversitesi, Konya.

Aldao A., Nolen-Hoeksema S., \& Schweizer S. (2010). Emotion-regulation strategies across psychopathology: A meta-analytic review. Clinical Psychology Review, 30(2), 217-237.

Altunkol, F. (2011). Üniversite öğrencilerinin bilişsel esneklikleri ile algllanan stres düzeyleri arasındaki ilişkinin incelenmesi. Yayımlanmamış yüksek lisans tezi, Çukurova Üniversitesi, Adana.

Anayurt, A. (2017). Duygu düzenleme ile erken dönem uyumsuz şemalar, bilişsel esneklik ve ruminasyon arasındaki ilişkilerin incelenmesi. Yayımlanmamış yüksek lisans tezi, Ankara Üniversitesi, Ankara.

Asıc1, E. ve İkiz, F.E. (2015). Mutluluğa giden bir yol: Bilişsel esneklik. Mehmet Akif Ersoy Üniversitesi Eğitim Fakültesi Dergisi, 35(3), 191-211.

Balkıs, M., Duru, E., Buluş, M. ve Duru, S. (2006). Üniversite öğrencilerinde akademik erteleme eğiliminin çeşitli değişkenler açısından incelenmesi. Ege Eğitim Dergisi, 2(7), 57-73.

Beleaua, R-E., \& Cocoradă, E. (2016). Procrastination, stress and coping in students and employees. Romanian Journal of Experimental Applied Psychology, 7(1), 191-195. 
Bilge, Y., Türk, T., Bilge, Y., \& Deniz, M. E. (2015). Sosyal problem çözme eğitim programının ergenlerin karar verme süreçleri üzerindeki etkilerinin incelenmesi. IZU Journal of Social Science, 3(6-7), 51-78.

Bilgiç, R. (2015). Ergenlerin cinsiyet ve öğrenim kademesi düzeylerine göre bilişsel esneklik düzeyleri ile karar stratejileri arasındaki iliş̧kinin incelenmesi. Yayımlanmamış yüksek lisans tezi, Bahçeşehir Üniversitesi, İstanbul.

Bilgin, M. (2017). Ergenlerin beş faktör kişilik özelliği ile bilişsel esneklik ilişkisi. Electronic Journal of Social Sciences, 16(62), 945-954.

Böke, K. (Ed.). (2010). Sosyal bilimlerde araştırma yöntemleri. İstanbul: Alfa Yayıncılık.

Bridges, K. R., \& Roig, M. (1997). Academic procrastination and irrational thinking: A re-examination with context controlled. Personality and Individual Differences, 22(6), 941994.

Broderick, P. C. \& Korteland, C. A. (2004). Prospective study of rumination and depression in early adolescence. Clinical Child Psychiatry and Psychology, 9, 383-394.

Bugay, A. ve Erdur-Baker, Ö. (2011). Ruminasyon düzeyinin toplumsal cinsiyet ve yaşa göre incelenmesi. Türk Psikolojik Danışma ve Rehberlik Dergisi, 4(36), 191-201.

Buğa, A., Özkamalı, E., Altunkol-Wise, F. ve Çekiç, A. (2019). Üniversite öğrencilerinin bilişsel esneklik düzeylerine göre sosyal problem çözme tarzlarının incelenmesi. Gaziantep Üniversitesi Eğitim Bilimleri Dergisi, 2(1), 48-58.

Bulut, R. (2014). Sosyal bilgiler ögretmen adaylarının akademik erteleme davranışlarının çeşitli değişkenler açısından incelenmesi. Yayımlanmamış yüksek lisans tezi, Afyon Kocatepe Üniversitesi, Afyon.

Burns, L. R., Dittmann, K., Nguyen, N., \& Mitchelson, J. K. (2000). Academic procrastination, perfectionism, and control: Associations with vigilant and avoidant coping. Journal of Social Behavior and Personality, 15(5), 35-46.

Büyüköztürk, Ş. (2007). Veri analizi el kitabı. (7. Baskı). Ankara: Pegem Akademi.

Büyüköztürk, Ş., Kılıç-Çakmak, E., Akgün, Ö. E., Karadeniz, Ş., ve Demirel, F. (2014). Bilimsel araştırma yöntemleri. (17. Baskı). Ankara: Pegem Yayınları.

Canas, J., Quesada, J., Antolí, A., \& Fajardo, I. (2003). Cognitive flexibility and adaptability to environmental changes in dynamic complex problem-solving tasks. Ergonomics,46(5), 482501.

Carter, J. D., Frampton, C.M.A., Mulder, R.T., Luty, S.R, McKenzie, J.M. \& Joyce, P.R. (2009). Rumination: Relationship to depression and personality in a clinical sample. Personality and Mental Health, 5(4), 275-283.

Cohen, J. (1988). Statistical power analysis for the behavioral sciences. (2nd ed.). Hillsdale: Lawrence Erlbaum Publishers.

Corkin, D. M., Yu, S. L., Wolters, C. A., \& Wiesner, M. (2014). The role of the college classroom climate on academic procrastination. Learning and Individual Differences, 32, 294-303.

Creswell, J. W. (2017). Eğitim araştırmalarl: Nicel ve nitel araştırmanın planlanmasl, yürütülmesi ve değerlendirilmesi. (H. Ekşi, Çev., Ed.). İstanbul: Edam.

Çakıcı, D. Ç. (2003). Lise ve üniversite ögrrencilerinde genel erteleme ve akademik erteleme davranışının incelenmesi. Yayımlanmamış yüksek lisans tezi, Ankara Üniversitesi, Ankara.

Çelikkaleli, Ö. (2014). Ergenlerde bilişsel esneklik ile akademik, sosyal ve duygusal yetkinlik inançları arasındaki ilişki. Eğitim ve Bilim, 39(176), 347-354.

Çıkrıkçı, Ö. ve Erzen, E. (2016). Cinsiyetin akademik erteleme üzerindeki etkisi: Meta-analiz. Hacettepe Üniversitesi Eğitim Fakültesi Dergisi (H. U. Journal of Education) 31(4), 750-761. 
Çuhadaroğlu, A. (2011). Bilişsel esnekliğin yordayıcıları. Yayımlanmamış doktora tezi, Ankara Üniversitesi, Ankara.

Çuhadaroğlu, A. (2013). Bilişsel esnekliğin yordayıcıları. Cumhuriyet Uluslararası Eğitim Dergisi, 2(1), 86-101.

Davis, R., \& Nolen-Hoeksema, S. (2000). Cognitive inflexibility among ruminators and nonruminators. Cognitive Therapy and Research, 24(6), 699-711.

Dennis, J.P., \& Vander Wal, J.S. (2010). The cognitive flexibility inventory: Instrument development and estimates of reliability and validity. Cognitive Therapy and Research, 34, 241-53.

Diril, A. (2011). Lise ögrrencilerinin bilişsel esneklik düzeylerinin sosyo-demografik değişkenler ve öfke düzeyi ile öfke ifade tarzları arasındaki iliş̧k açısından incelenmesi. Yayımlanmamış yüksek lisans tezi, Çukurova Üniversitesi, Adana.

Doğan-Laçin, B. G. (2015). Üniversite öğrencilerinde öz yeterlilik ve stresle başa çıkma stratejilerinin bilişsel esnekliği yordama düzeyleri. Yayımlanmamış yüksek lisans tezi, Ankara Üniversitesi, Ankara.

Ebata, A. T., \& Moos, R. H. (1991). Coping and adjustment in distressed and healthy adolescents. Journal of Applied Developmental Psychology, 12, 33-54.

Endler, N. S., Kantor, L., \& Parker, J. D. A. (1994). State-trait coping, state-trait anxiety and academic performance. Personality and Individual differences, 16(5), 663-670.

Erdur-Baker, O. \& Bugay, A. (2012). The Turkish version of the Ruminative Response Scale: An examination of its reliability and validity. The International Journal of Educational and Psychological Assessment, 10(2), 1-16.

Ewen, R. B. (2003). An introduction to theories of personality. (6th ed.). New Jersey: Lawrence Erlbaum Associates.

Flett, G.L., Stainton, M., Hewitt, P.L., Sherry, S.B., \& Lay, C. (2012). Procrastination automatic thoughts as a personality construct: An analysis of the procrastinatory cognitions inventory. Journal of Rational-Emotive and Cognitive-Behavior Therapy, 30, 223-236.

Gareau, A., Chamandy, M., Kljajic, K., \& Gaudreau, P. (2018). The detrimental effect of academic procrastination on subsequent grades: The mediating role of coping over and above past achievement and working memory capacity. Anxiety, Stress \& Coping (Online). doi: 10.1080/10615806.2018.1543763

Genet, J. J., Malooly, A. M., \& Siemer, M. (2013). Flexibility is not always adaptive: Affective flexibility and inflexibility predict rumination use in everyday life. Cognition and Emotion, 27(4), 685-695.

Greene, T. C. (2019). Pathways to coping to with extreme events: A study of the relations between cognitive flexibility and four types of rumination. Unpublished master's thesis, The University of North Carolina, Charlotte, USA.

Güler, A. S. (2009). Tourette sendromu olan çocuk ve ergenlerde bilişsel esneklik ve sosyal karşıllkkllık. Uzmanlık tezi, Marmara Üniversitesi, İstanbul.

Johnson, J. L., \& Bloom, A. M. (1995). An analysis of the contribution of the five factors of personality to variance in academic procrastination. Personality ve Individual Differences, $18,127-133$.

Jose, P. \& Brown, I. (2008). When does the gender difference in rumination begin? Gender and age differences in the use of rumination by adolescents. Journal of Youth and Adolescence, 37(2), 180-192. 
Kağan, M. (2010). Akılcı duygusal davranışsal yaklaşıma dayalı akademik erteleme davranışını önleme programının etkililiğinin değerlendirilmesi. Yayımlanmamış doktora tezi, Ankara Üniversitesi, Ankara.

Kandemir, M. (2014). Akademik erteleme davranışını açıklayıcı bir model. Pegem Eğitim ve Ögretim Dergisi, 4(3), 51-72.

Kaya-Kızılöz, B. (2018). Interrelationships between autobiographical memory, specificity, executive functions and rumination in depression. Yayımlanmamış doktora tezi, Boğaziçi Üniversitesi, İstanbul.

Kı1ıç, S. (2016). Cronbach'ın alfa güvenirlik katsayısı. Journal of Mood Disorders, 6(1), 47-48.

Kömür, B. E. (2018). Üniversite ögrrencilerinde bilişsel esneklik ile stresle başa çıkma becerileri arasındaki ilişskinin araștırılması. Yayımlanmamıs yüksek lisans tezi, Üsküdar Üniversitesi, İstanbul.

Lay, C. H. (1986). At last, my research article on procrastination. Journal of Research in Personality, 20, 474-495.

Lay, C. H., Edwards, J. M., Parker, J. D. A. \& Endler, N. S. (1989). An assessment of appraisal, anxiety, coping, and procrastination during an examination period. European Journal of Personality, 3(3), 195-208.

Lay, C. H., \& Schouwenburg, H. C. (1993). Trait procrastination, time management, and academic behavior. Journal of Social Behavior and Personality, 8(4), 647- 662.

Lazarus, R. S. (1966). Psychological stress and the coping process. New York, US: McGraw Hill.

Lazarus, R. S., \& Folkman, S. (1984). Stress, appraisal, and coping. New York, NY: Springer Publishing.

Lee, D., Kelly, K., \& Edwards, J. (2006). A closer look at the relationships among trait procrastination, neuroticism, and conscientiousness. Personality and Individual Differences, 40, $27-37$.

Lyubomirsky, S., Tucker, K. L., Caldwell, N. D. \& Berg, K. (1999). Why ruminators are poor problem solvers. Clues from the phenomenology of dysphoric rumination. Journal of Personality and Social Psychology, 77(5), 1041-1060.

Macan, T. (1994). Time management: Test of a process model. Journal of Applied Psychology, 79, 381-391.

Marshall, M. N. (1996). Sampling for qualitative research. Family practice, 13(6), 522-526.

Martin, D. J., Oren, Z., \& Boone, K. (1991). Major depressives' and dysthymics' performance on the Wisconsin Card Sorting Test. Journal of Clinical Psychology, 47, 684-690.

Martin, M. M., \& Anderson, C. M. (1998). The cognitive flexibility scale: Three validity studies. Communication Reports, 11(1), 1-9.

Martin, M. M., \& Rubin, R. B. (1995). A new measure of cognitive flexibility. Psychological Reports, 76, 623-626.

Monsell, S. (2003). Task switching. Trends in cognitive sciences, 7, 134-140.

Neenan, M. (2008). Tackling procrastination: An REBT perspective for coaches. Journal of Rational-Emotive \& Cognitive-Behavior Therapy, 26(1), 53-62.

Neziroğlu, G. (2010). Ruminasyon, yaşantısal kaçınma ve problem çözme becerileri ile depresif belirtiler arasındaki ilişkilerin incelenmesi. Yayımlanmamış yüksek lisans tezi, Hacettepe Üniversitesi, Ankara.

Nolen-Hoeksema, S. (1991). Responses to depression and their effects on the duration of depressive episodes. Journal of Abnormal Psychology, 100, 569-582. 
Nolen-Hoeksema, S. (2000). The role of rumination in depressive disorders and mixed anxiety/depressive symptoms. Journal of Abnormal Psychology, 109(3), 504-511.

Nolen-Hoeksema, S., \& Morrow, J. (1991). A prospective study of depression and post-traumatic stress symptoms following a natural disaster: The 1989 Loma Prieta Earthquake. Journal of Personality and Social Psychology, 61(3), 115-121.

Nolen-Hoeksema, S., Wisco, B. E., \& Lyubomirsky, S. (2008). Rethinking rumination. Perspectives on Psychological Science, 3(5), 400-424

Owens, M., \& Derakshan, N. (2013). The effects of dysphoria and rumination on cognitive flexibility and task selection. Acta Psychologica, 142, 323-331.

Öz, S. (2012). Ergenlerin cinsiyet, sosyo-ekonomik ve öğrenim kademesi düzeylerine göre bilişsel esneklik, uyum ve kaygı puanları arasındaki ilişkinin incelenmesi. Yayımlanmamış yüksek lisans tezi, Çukurova Üniversitesi, Adana.

Roth, S., \& Cohen, L. J. (1986). Approach, avoidance, and coping with stress. American Psychologist, $41,813-819$.

Scher, J. S., \& Osterman, N. M. (2002). Procrastination, conscientiousness, anxiety, and goals: Exploring the measurement and correlates of procrastination among school-aged children. Psychology in the Schools, 39(4), 385-398.

Schommer-Aikins, M., \& Easter, M. (2018). Cognitive flexibility, procrastination, and need for closure linked to online self-directed learning among students taking online courses. Journal of Business and Educational Leadership, 8(1), 112-121.

Senécal, C., Julien, E., \& Guay, F. (2003). Role conflict and academic procrastination: A self determination perspective. European Journal of Social Psychology, 33(1), 135-145.

Siegle, G. J., Moore, P. M. \& Thase, M. E. (2004). Rumination: One construct, many features in healthy individuals, depressed individuals, and individuals with lupus. Cognitive Therapy and Research, 28(5), 645-668.

Silver, J. A., Hughes, J. D., Bornstein, R. A., \& Beversdorf, D. (2004). Effect of anxiolytics on cognitive flexibility in problem solving. Cognitive Behavioral Neurology, 17, 93-97

Sirois, F. M. \& Kitner, R. (2015). Less adaptive or more maladaptive? A meta-analytic investigation of procrastination and coping. European Journal of Personality, 29, 433-444.

Solomon, L. J., \& Rothblum, E. D. (1984). Academic procrastination: Frequency and cognitive behavioral correlates. Journal of Counseling Psychology, 31(4), 503.

Stainton, M., Lay, C. H., \& Flett, G. L. (2000). Trait procrastinators and behavior/trait-specific cognitions. Journal of Social Behavior and Personality, 15, 297-312.

Stevens, A. D. (2009). Social problem solving and cognitive flexibility: Relations to social skills and problem behaviour of at-risk young children. Unpublished doctoral dissertation, Seattle Pacific University, USA.

Treynor, W., Gonzalez, R., \& Nolen-Hoeksema, S. (2003). Rumination reconsidered: A psychometric analysis. Cognitive Therapy and Research, 27(3), 247-259.

Uzun-Özer, B., Demir, A., \& Ferrari, J.R. (2009) Exploring academic procrastination among Turkish students: Possible gender differences in prevalence and reasons. The Journal of Social Psychology, 149(2), 241-257.

Van Berkel, H. (2009). The relationship between personality, coping styles and stress, anxiety and depression. Yayımlanmamış yüksek lisans tezi, University of Canterbury. ProQuest Dissertations and Thesis veri tabanından erişildi.

Vodanovich, S. J., \& Seib, H. M. (1997). Relationship between time structure and procrastination. Psychological Reports, 80(1), 211-215. 
Zong, J., Cao, X. Y., Cao, Y., Shi, Y. F., Wang, Y. N., \& Yan, C. (2010). Coping flexibility in college students with depressive symptoms. Health and Quality of Life Outcomes, 8(66), 1-6. 